\section{OAK RIDGE NATIONAL LABORATORY}

MARTIN MARIFTIA
Modeling and Analysis of Core Debris Recriticality During Hypothetical Severe Accidents in the Advanced Neutron Source Reactor

\author{
R. P. Taleyarkhan \\ S. H. Kim \\ C. O. Slater \\ D. L. Moses \\ D. B. Simpson \\ V. Georgevich
}


This report has been reproduced directly from the best available copy.

Available to DOE and DOE contractors from the Office of Scientific and Technical Information, P.O. Box 132, Oak Ridge, TN 37831; prices available from (615) 576-8401, FTS 626-8401.

Available to the public from the National Technical Informb in Service, U.S. Department of Commerce, 5285 Port Royal Rd., Springfield, VA 22161.

This report was prepared as an account of work sponsored by an agency of the United States Government. Neither the Urited States Government nor any agency thereof, nor any of their employees, makes any warranty, express or implied, or assumes any legal liability or responsibility for the accuracy, completeness, or usefulness of any information, apparatus, product, or process disclosed, or represents that its use would not infringe privately owned rights. Reference herein to any specific commercial product, process, or service by trade name, trademark, manufacturer, or otherwise, does not necessarily constitute or imply its endorsement, recommendation, or favoring ky the United States Government or any agency thereof. The views and opinions of authors expressed herein do not necessarily state or reflect those of the United States Government or any agency thereuf. 
ORNL/TM-12382

ENGINEERING TECHNOLOGY DIVISION

\section{MODELING AND ANALYSIS OF CORE DEBRIS RECRITICALITY DURING HYPOTHETICAL SEVERE ACCIDENTS IN THE ADVANCED NEUTRON SOURCE REACTOR}

R. P. Taleyarkhan, S. H. Kim, C. O. Slater,

D. L. Moses, D. B. Simpson, and

V. Georgevich

May 1993






\section{TABLE OF CONTENTS}

\section{Page}

LIST OF TABLES ....................................................................................

LIST OF FIGURES ............................................................................ iv

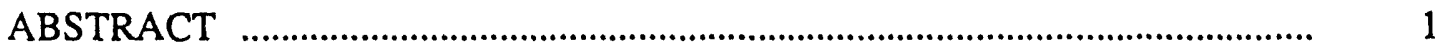

1 INTRODUCTION _........................................................................

1.1 ANS System Design ..............................................................................

1.2 Importance of Recriticality Issue for ANS ...........................................

2 MODELING AND PROBLEM FORMULATION FOR ANS

RECRITICALITY ANALYSES …............................................................ 2

$\begin{array}{llll}2.1 & \text { Modeling Framework Development, Benchmarking and Validation } & \ldots & 3\end{array}$

2.2 Establishing a Bias for the Calculated keff .................................................

3 ANS DEBRIS RECRITICALITY MODELING AND ANALYSIS $\quad \ldots \ldots \ldots . . . . . \quad 5$

3.1 Test Matrix Development and Modeling ….......................................... 5

3.2 Analysis Results .......................................................................... 7

3.2.1 Analysis results for cases from Table 4 ................................. 7

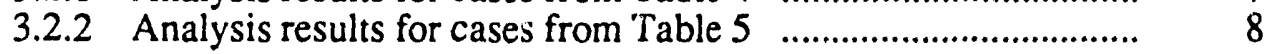

3.3 Prevention and Mitigation of Debris Recriticality Loads in ANS ........ 9

4 SUMMARY AND CONCLUSIONS $\quad$......................................................... 9

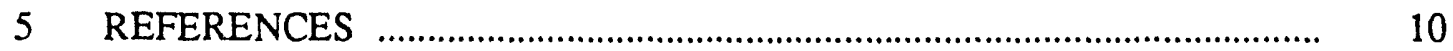




\title{
MODELING AND ANALYSIS OF CORE DEBRIS RECRITICALITY DURING HYPOTHETICAL SEVERE ACCIDENTS IN THE ADVANCED NEUTRON SOURCE REACTOR
}

\author{
R. P. Taleyarkhan, S. H. Kim, C. O. Slater, D. L. Moses, \\ D. B. Simpson, and V. Georgevich
}

\begin{abstract}
This paper discusses salient aspects of severe-accident-related recriticality modeling and analysis in the Advanced Neutron Source (ANS) reactor. The development of an analytical capability using the KENO V.A-SCALE system is described including evaluation of suitable nuclear cross-section sets to account for the effects of system geometry, mixture temperature, material dispersion and other thermal-hydraulic conditions. Benchmarking and validation efforts conducted with KENO V.A-SCALE and other neutronic codes against critical experiment data are described. Potential deviations and biases resulting from use of the 16-group Hansen-Roach library are shown. A comprehensive test matrix of calculations to evaluate the threat of a recriticality event in the ANS is described. Strong dependencies on geometry, material constituents, and thermal-hydraulic conditions are described. The introduction of designed mitigative features is described.
\end{abstract}

\section{INTRODUCTION}

Oak Ridge National Laboratory's (ORNL's) Advanced Neutron Source (ANS) reactor will be a new user facility 1,2 for a broad range of neutron research, centered around a research reactor of unprecedented $\left(\sim 10^{20} \mathrm{~m}^{-2} \cdot \mathrm{s}^{-1}\right)$ neutron flux available to the beam tubes. A defense-in-depth philosophy has been adopted. In response to this commitment, ANS Project management has initiated severe accident analysis and related technology development early in the design phase. This was done to aid in designing a sufficiently robust containment for retention and controlled release of radionuclides in the event of an accident. It also provides a means for satisfying on- and off-site regulatory requirements and accident-related dose exposures and for containment response and source-term best-estimate analyses for the Levels- 2 and -3 Probabilistic Risk Analyses (PRAs) that will be produced. Moreover, it will provide the best possible understanding of the ANS under severe accident conditions and consequently provide insights for development of strategies and design philosophies for accident mitigation, management, and emergency preparedness efforts.

This report describes salient aspects of the work done to date on addressing a potentially important severe accident issue dealing with recriticality during hypothetical severe accidents. 


\subsection{ANS SYSTEM DESIGN}

The ANS is currently in the conceptual design stage. As such, design features of the containment and reactor system are evolving based on insights from ongoing studies. Table 1 summarizes the current principal design features of the ANS from a severe accident perspective compared to ORNL's High Flux Isotope Reactor ${ }^{3}$ (HFIR) and a commercial light-water reactor (LWR). As seen in Table 1, high-power-density research reactors can give rise to significantly different severe accident issues. Specifically, the ANS reactor will use about $15 \mathrm{~kg}$ of highly enriched $(-93 \mathrm{~m} / \mathrm{o} 235 \mathrm{U})$ uranium silicide fuel in an aluminum matrix with a plate-type geometry and a total core mass of $100 \mathrm{~kg}$. About $13 \mathrm{~g}$ of $\mathrm{B}^{10}$ burnable poison is provided in the end caps of fuel plates to reduce excess reactivity at the beginning of cycle (BOC) and to help shape the power distribution. Heavy water $\left(\mathrm{D}_{2} \mathrm{O}\right)$ is used as moderator and coolant. The power density of the ANS will be about 50 to 100 times higher than that of a large light water reactor (LWR). A schematic representation of the reactor and cooling circuit is given in Fig. 1. The reactor core is enclosed within a core pressure boundary tube and enveloped in a reflector tank. Four inlet pipes deliver $\mathrm{D}_{2} \mathrm{O}$ coolant upward through the core at a high velocity $(-25 \mathrm{~m} / \mathrm{s})$, and $\mathrm{D}_{2} \mathrm{O}$ then enters a large stainless steel pipe before branching inio several pipes leading to heat exchangers. Much of the coolant system piping is submerged in light-water pools.

\subsection{IMPORTANCE OF RECRITICALITY ISSUE FOR ANS}

Recriticality during severe accidents could lead to damaging steam explosion loads. Additional fission product generation and high-energy bursts of radiation are also undesirable byproducts. The scoping study of recriticality in ANS under hypothetical severe accidents was motivated by the need to gage the potential for such an occurrence and by the need to consider designed mitigative features early in the design process.

Work conducted for this report is presented in several chapters. Chapter 2 presents a discussion of the mathematical modeling, benchmarking and numerical simulation of various potential geometries that may lead to recriticality in the ANS. The simulation capability developed was then used to conduct analysis for several potential configurations and parametric values for the ANS. This is described in Chap. 3. Thereafter, Chap. 4 presents a summary and conclusion of the work presented in this report.

\section{MODELING AND PROBLEM FORMULATION FOR ANS RECRITICALITY ANALYSES}

During hypothetical severe accidents in the ANS, fuel plate melting may occur either with or without a flowing medium adjacent to the melting plates. Hypothetical accident conditions such as core inlet flow blockages or large pipe loss-of-coolant accidents (LOCAs) may provide such conditions. Under such circumstances, and assuming that a steam explosion does not occur, the core mass may slump and agglomerate downward into the primary coolant system piping regions. Again, experiments ${ }^{4}$ with melting aluminum tubes in the presence of flowing media have shown that depending on the destabilizing surface forces caused by flowing media, debris dispersal and entrainment in the flowing medium may occur. Debris dispersal also may occur in the presence of steam explosions. Such dispersion mechanisms can cause 
fragmented core debris to be swept into the coolant outlet piping. Hence, for ANS severe accident analysis, lumped and dispersed configurations need to be analyzed for gauging recriticality potential.

The process of modeling and analysis for recriticality under severe accident conditions for ANS involved several steps. First, a modeling capability was developed to account for ANS debris in various configurations and surrounded with various geometries and materials. The modeling framework was benchmarked and validated against known critical experiments. Next, the potential for recriticality in the ANS under severe accident conditions was analyzed. Because of the absence of a mechanistic core-melt-progression capability, the various geometries and thermal-hydraulic conditions were postulated and analyzed parametrically. Again, the time-dependent behavior of the system following a recriticality event would require development of a transient modeling capability, which was considered beyond the scope of this simplified study. Hence, a wide range of parametric studies was conducted to gauge the behavior of the system under various conditions of temperature and void fraction. Finally, evaluations were made for incorporation of designed mitigative features for prevention of recriticality. Salient aspects of these various steps are described subsequently.

\subsection{MODELING FRAMEWORK DEVELOPMENT, BENCHMARKING, AND VALIDATION}

Because of its versatility, the well-known KENO V.A-SCALE ${ }^{5}$ neutronic code system was the modeling frame-work of choice for evaluating the recriticality potential of ANS core debris. To gage applicability of this system to ANS debris lumped or dispersed geometries, a series of experiments was researched. These experiments considered lumped and dispersed fuel configurations in the presence of light and heavy water. In addition to using KENO V.A for evaluating $k_{c f f}$, transport-theory-based (viz., XSDRNPM, ${ }^{5}$ TORT $^{6}$ ) calculations also were conducted to provide a basis for bias determination and for evaluating the appropriateness of using the 39- and 99-group ANSL-V cross-section libraries. ${ }^{\top}$ Several details of the comparison are omitted because of space considerations. An abstract of the benchmarking and validation exercises is presented.

Results of KENO V.A and XSDRNPM calculations for $\mathrm{k}_{\mathrm{eff}}$ against the wellknown GODIVA ${ }^{8}$ bare enriched U-metal sphere experiment are given in Table 2 . Note that criticality is evaluated within one standard deviation of the experiment. This forms an important benchmark for the cross-section libraries used in analysis of ANS reactor lumped-core cases. Thereafter, ancillary calculations were performed with XSDRNPM and KENO V.A for three $\mathrm{H}_{2} \mathrm{O}$-reflected spheres and five $\mathrm{D}_{2} \mathrm{O}$-reflected spheres. The results of XSDRNPM and KENO V.A agreed within one standard deviation of individual calculations, representing excellent comparisons.

Five ORNL critical spheres ${ }^{9}$ consisting of enriched uranyl nitrate in water in one of two spheres of radius 345.98 or $610.108 \mathrm{~mm}$ (the first four spheres having the smaller radius) were analyzed. The first and fifth spheres contain the critical concentrations for unpoisoned solutions within the two spheres. In the other three, criticality is maintained by counterbalancing increases in the uranium concentration with increases in the natural boron concentration of the solution. Selected results are presented in Table 2. The results of computations are within $0.25 \%$ uncertainty of the experiments, and again, excellent agreement is seen between predictions and experiment, and between XSDRNPM and KENO V.A calculations. Also, note that use of 39- and 99-group crosssections gives almost identical results. Separately, additional comparisons also were made against six $\mathrm{D}_{2} \mathrm{O}$-reflected spheres 10 and five bare cylinders filled with uranyl fluoride in heavy water using XSDRNPM and DORT. Excellent agreement was obtained 
between predictions and experiments. Separately, five supplemental ORNL-reflected and bare critical spheres consisting of enriched uranyl fluoride in water were analyzed. These experiments supplemented the earlier uranyl nitrate sphere comparisons in that a wider range of $\mathrm{H} / 235 \mathrm{U}$ ratios was introduced, and reflected spheres were included. Predictions were made with both the ANSL-V 39- and 99-group cross-section libraries in the SCALE system and with XSDRNPM to perform k-calculations. As noted in Table 2, calculated results were found to be in excellent agreement with experimental data and confirm applicability of the ANSL-V cross-section libraries in the SCALE system. Together, the above-mentioned comparisons provide reasonable confidence in the utility of the KENO V.A-SCALE system for evaluation of $k_{\mathrm{eff}}$ values for ANS core debris in either lumped or dispersed configurations for the range of $D / 235$ values in the experiments.

An interesting plot showing the various experimental data (lumped and dispersed configurations) used for the comparison exercises is given in Fig. 2. Figure 2 displays critical mass size on the ordinate versus $\mathrm{D} / 235 \mathrm{U}$ ratio on the abscissa. As can be noted, the comparisons were made over a fairly wide range of $D / 235 \mathrm{U}$ ratios (i.e., from 230 to 2080). It is expected that for the most part, the value of $D / 235 \mathrm{U}$ will fall within this range. For values of this ratio beyond this range, it will be assumed that the results of KENO-SCALE calculations with 39-group cross-sections will be valid.

The KENO V.A-SCALE system was ported to work on an IBM/RISC-6000 workstation platform. During this porting exercise, from machine dependency considerations the random number generator supplied by the mainframe version had to be revised. Further details are documented in configuration control documents detailing the various changes made. Twenty-five benchmark calculations were executed using the integrated system. Results of comparison against 25 standard KENO V.A sample problems are shown in Table 3. As noted from Table 3, excellent agreement was obtained between KENO V.A-SCALE on the ORNL mainframe and on the workstation computers (using the revised random number generator). This exercise verified the correctness of portability of the KENO-SCAiE on to the IBM RISC/6000 workstation platform.

Prior to porting of KENO-SCALE, an IBM/PC version of the KENO V.A code named KENO V.A.PC was also ported to the IBM RISC/6000 platform. This version was also benchmarked against the 25 standard problems, and good agreement was obtained. However, it should be mentioned at this stage that KENO V.A-PC only allows for use of the Hansen-Roach cross-section libraries. Resonance self-shielding correction factors are included indirectly by the user having to specify appropriate identifiers based on so-called $s_{p}$ correction factors. These correction factors become important for situations where significant quantities of $238 \mathrm{U}$ are present. A major shortcoming of the KENO V.A-PC version 11 is that the user is limited to use the 16-group cross-section sets. Errors incorporated from this limitation will be highlighted in the next chapter. Another limitation was the fact that the cross-section sets of KENO V.A-PC do not allow evaluation of temperature dependence on criticality, since the Hansen-Roach library was developed under room temperature conditions. Despite these limitations, the KENO V.A-PC code was useful for conducting initial parametric studies.

\subsection{ESTABLISHING A BIAS FOR THE CALCULATED $\mathrm{k}_{\mathrm{e} f}$}

Because, for a critical system, $\mathrm{k}$ eff $=1.0$, deviations of the calculated values from unity indicate some bias in the calculational methods and/or data. To ensure subcriticality of the ANS core debris, the calculated $k_{\text {eff }}$ values should be below established limits. The established limits are set at $k^{\text {avg }}-3 s-0.02$ (where 0.02 has been subtracted for extra shutdown margin as recommended in Ref. 12). From comparison of the SCALE system results for $k_{\mathrm{cff}}$, for both lumped and dispersed configurations, one 
arrives at bias $\mathrm{k}_{\mathrm{eff}} \mathrm{s}^{\mathrm{s}}$ of 0.965 for lumped and dispersed geometries. Thus, any configuration with a calculated keff greater than 0.965 would be considered critical.

\section{ANS DEBRIS RECRITICALITY MODELING AND ANALYSIS}

The modeling framework described in Chap. 2 was used to conduct scoping analyses for various ANS debris configurations. At this stage, it should be mentioned that the ANS system is still being developed. Previous core designs consisted of $\sim 26 \mathrm{~kg}$ of ${ }^{235} \mathrm{U}$, which now has been reduced to $15 \mathrm{~kg}$. It is felt that the present conceptual core design utilizing $15 \mathrm{~kg}$ of $235 \mathrm{U}$ will not be changed substantially. Calculations for $\mathrm{k}_{\mathrm{eff}}$ with the larger fuel loading and different reactor coolant system piping diameter also have been conducted and are reported here for completeness, and also to indicate important trends. To evaluate the threat of a recriticality event under different conditions, several different configurations and thermai-hydraulic conditions needed to be analyzed. The development of a suitable test matrix and analysis results are described subsequently.

\subsection{TEST MATRIX DEVELOPMENT AN'J MODELING}

The test matrix of calculations is shown in Tables 4 and 5. Cases identified in Table 4 were made using system geometrical parameters and fuel mass compositions used in preconceptual ANS designs, whereas runs made with conceptual core and system designs are shown in Table 5. As noted, calculations for $k_{\text {eff }}$ were conducted with lumped and dispersed core debris materials in a stainless steel pipe filled with $\mathrm{D}_{2} \mathrm{O}$ and reflected on the outside by $\mathrm{H}_{2} \mathrm{O}$. The lumped configurations were analyzed first and were found to be relatively unimportant. Because of the importance of dispersed configurations, most parametric calculations were conducted in dispersed geometries. As mentioned previously, lumped configurations are studied in a smaller diameter pipe [approximating the preconceptual core inlet piping of 483-mm (19-in.) inner diameter and 10 -mm thickness; currently, the ANS core inlet piping has an inner diameter of 356-mm with a thickness of $9.5 \mathrm{~mm}$ ]. Dispersed configurations are studied for debris dispersal in the $483-\mathrm{mm}$ (19-in.) piping as well as in $610-\mathrm{mm}$ (24-in.) schedule 20 outlet piping. Where not specifically indicated, a room temperature assumption was used for the calculations, for conservatism. Again, unless otherwise indicated, the core debris is assumed to be contained in a pipe volume extending over $3 \mathrm{~m}$. Dispersed configurations are assumed to be uniformally distributed along the bottom of the pipe over a length of 1 $\mathrm{m}$, unless otherwise stated in Table 5.

Typical geometries for lumped and dispersed debris recriticality calculations are shown in Figs. 3 and 4 . Where the modeled regions are divided into four material zones. Zone 1 comprises the fueled zone. A reflecting boundary (Zone 2) extends to a distance of $1 \mathrm{~m}$ from both ends of the mixing or fuel zone. The $1-\mathrm{m}$ length was calculated essentially to provide infinite reflection of neutrons. The stainless steel piping constitutes Zone 3. Finally, the $\mathrm{H}_{2} \mathrm{O}$ outside the primary coolant piping is represented as Zone 4.

As mentioned previously, lumped fuel calculations (even with $26 \mathrm{~kg}$ of $235 \mathrm{U}$ ) gave rise to subcritical values of $k_{\text {eff. }}$. Cases $1-3$ in Table 4 were set up to demonstrate this aspect. Case 1 considered a situation where the entire preconceptual core mass consisting of $\mathrm{U}_{3} \mathrm{Si}_{2}$ (with $26 \mathrm{~kg}$ of $235 \mathrm{U}$ ) without any of the aluminum forms a $175-\mathrm{mm}$ dia. lump in a $\mathrm{D}_{2} \mathrm{O}$-filled steel pipe surrounded with water. Case 2 is similar to Case 1 , with the exception that core aluminum mass is included. Case 3 considers the possibility that the core mass of $\mathrm{U}_{3} \mathrm{Si}_{2}$ (without aluminum) assumes the shape of the pipe. Unlike lumped configurations, it was found thist significant possibility exists for dispersed 
configurations to undergo recriticality. Cases 4 to 6 with various amounts of $\mathrm{U}_{3} \mathrm{Si}_{2}$ fuel were set up to study this phenomenon. Case 7 was set up to evaluate the effect of the external $\mathrm{H}_{2} \mathrm{O}$ reflector, whereas Case 8 was set up to study the effect of poisoning the stainless steel pipe with natural boron. Finally, to evaluate the impact of pipe material, Case 9 was introduced where the pipe material is changed from steel to aluminum. For all cases studied in Table 4 , the $13 \mathrm{~g}$ of $\mathrm{B}^{10}$ burnable poison present in the ANS conceptual core fuel plates was not included.

Due to the relative importance of dispersed geometries, a detailed test matrix was developed for parametrically evaluating the effects of changes in important variables using conceptual core and coolant system design parameters. The resulting test marix is shown in Table 5. The base case was developed where coolant temperature is set at $50^{\circ} \mathrm{C}$ to represent nominal coolant outlet temperature of the ANS core under normal operation (instead of assuming room temperature). BOC inventory of fuel is assumed for the base case, coupled with all of the $13 \mathrm{~g}$ of $\mathrm{B}^{10}$ burnable poison. It was assumed that upon fuel melting-cum-dispersion, only the aluminum in the fuel meat section would accompany the fuel. Hence, about $40 \mathrm{~kg}$ of aluminum is associated with the base case debris recriticality calculations in Table 5. Further, it is assumed that the fuel debris would cool down to $50^{\circ} \mathrm{C}$ by the time the $1-\mathrm{m}$-length dispersion occurs in the outlet piping. Based on ANS Technical Specifications, the amount of $\mathrm{H}_{2} \mathrm{O}$ contamination in the $\mathrm{D}_{2} \mathrm{O}$ is specified to a mole fraction of 0.002 [i.e., assuming no influx of reactor pool $\mathrm{H}_{2} \mathrm{O}$ in the reactor coolant system (RCS)].

Under certain circumstances, it is conceivable that the $\mathrm{H}_{2} \mathrm{O}$ fraction in the primary coolant circuit may increase (e.g., LOCA or in leakage). An increase in $\mathrm{H}_{2} \mathrm{O}$ content in the primary circuit will significantly change the neutronic characteristics associated with debris recriticality. This is caused by the significantly enhanced moderation by $\mathrm{H}_{2} \mathrm{O}$ compared to $\mathrm{D}_{2} \mathrm{O}$. However, this increased moderation characteristic is compensated by higher absorption. To capture such interactions, several mole fractions of $\mathrm{H}_{2} \mathrm{O}$ are included in the test matrix.

An important parameter that can significantly affect reactivity is the degree of voiding generated in the coolant. Such voiding may initiate in a previously cold system that has become critical, whereby the fuel maierial heats up to cause coolant boiling. For purposes of modeling, voids are assumed to be homogeneously distributed in Zone 1 (i.e., with fuel, $\mathrm{D}_{2} \mathrm{O}$, and $\mathrm{H}_{2} \mathrm{O}$ ). As is well known, increased voiding can provide negative reactivity feedback, which then may shut down the criticality escalation. Several KENO V.A-SCALE calculations are included in the test matrix. For these calculations, the fuel mixture (i.e., U, Si, B, Al) is assumed to be at the aluminum melting temperature of $660^{\circ} \mathrm{C}$. Herein, a conservative assumption is made that heat from the core debris goes only toward changing phase in the coolant. However, the coolant temperature also may increase. Therefore, additional calculations are included in the test matrix with Zone 1 contents equilibrated at $72^{\circ} \mathrm{C}$ (i.e., perfect mixing of fuel at melting temperature with 281 $\mathrm{kg}$ of $\mathrm{D}_{2} \mathrm{O}$ ). An additional case considered the entire mixture at $100^{\circ} \mathrm{C}$. This was done to represent a possible situation wherein molten core debris may have superheated above the aluminum melting temperature and then mixed with the $\mathrm{D}_{2} \mathrm{O}$ coolant to reach boiling conditions at atmospheric pressure. These calculations evaluate the effect of temperature on reactivity. The effect of temperature on fuel arises mainly from Doppler broadening. Hence, the fuel temperature coefficient of reactivity is determined mainly by resonance absorption. Because moderator density decreases with increasing temperature, the moderator coefficient of reactivity may be atributed to the change in thermal utilization. For these calculations, densities of $\mathrm{D}_{2} \mathrm{O}$ and $\mathrm{H}_{2} \mathrm{O}$ are suitably changed with temperature to account for the appropriate reduction in number densities of hydrogen, deuterium, and oxygen atoms. Densities of other materials are assumed to remain unchanged.

As mentioned previously, the 1-m length of the fuel debris mixture (i.e., Zone 1) was chosen arbirarily. Clearly, a change in this length will cause the D U ratio to 
change. Therefore, system criticality also can be significantly affected. Hence, parametric studies are conducted for different dispersion lengths.

Different amounts of aluminum may accompany the fuel debris in a severe accident. Hence, calculations are conducted to account for this effect.

Also, a severe accident-induced debris recriticality may occur at the end of the cycle (EOC) when -30 to $40 \%$ of the $235 \mathrm{U}$ and all of the $\mathrm{B}^{10}$ are depleted. These cases also are studied conservatively, assuming the absence of fission product poisoning. Note that the EOC case with about $40 \% 235 \mathrm{U}$ depleted would also tend to represent a case wherein only the unirradiated outer fuel element undergoes a bypothetical severe accident-induced core debris dispersion (albeit without any bumable poison).

\subsection{ANALYSIS RESULTS}

Specific KENO V.A models for the various cases in Tables 4 and 5 were set up and executed. The results of the $k_{\text {eff }}$ calculations are summarized in the tables and are shown graphically in Figs. 5 through 10. Unless otherwise stated, all calculations were conducted with the KENO V.A-SCALE system using the 39-group cross-section library. Analysis results for cases considered in Tables 4 and 5 are discussed separately.

\subsubsection{Analysis Results for Cases From Table 4}

As noted in Table 4 for Case 1, even if all of the $\mathrm{U}_{3} \mathrm{Si}_{2}$ (with $26 \mathrm{~kg}$ of $235 \mathrm{U}$ ) were to form a lump, the system would only be marginally critical based on our bias keff of 0.965. KENO and TORT calculations are in good agreement. For a more realistic case where the aluminum accompanies the silicide fuel mass and forms a lump with a $10 \%$ voidage, the system remains significantly subcritical (i.e., keff $=0.873$ ). For a hemispherical geomerry, even if none of the aluminum is included, the system remains significantly subcritical (i.e., $k_{\text {eft }}=0.819$ for Case 3 ). For the same pipe geometry and fuel compositions, a dispersed configuration produces significantly higher $k_{e f f}$ values as seen for Cases 4 and 5 . As noted for Cases 4 and 5 , even if the $235 U$ mass is reduced from $26 \mathrm{~kg}$ to $15 \mathrm{~kg}$, the keff value drops only slightly, from 1.09 to 1.07 . However, a dilui: concentration of $U_{3} S_{2}$ in a $2-m$ length pipe with $4.5 \mathrm{~kg}$ of $235 \mathrm{U}$ gives rise to a significantly subcritical configuration, thereby indicating a significant nonlinear variation of $k_{\text {eff }}$ with $235 \mathrm{U}$ mass.

Results for Case 7 (Table 4) indicate the relative importance of an $\mathrm{H}_{2} \mathrm{O}$ reflector. As noted, the keff value drops from a high value of 1.09 (for Case 4) to a subcritical value of 0.928 . This result is not surprising since water provides improved moderation for thermal neutrons and also acts as a reflector. The absorption of thermal neutrons is significantly compensated by a much greater scattering cross section. 13 As a reference, under room temperature conditions, the absorption cross section for $\mathrm{H}_{2} \mathrm{O}$ is about 0.664 bams (versus 0.001 bams for $\mathrm{D}_{2} \mathrm{O}$ ), but the scattering cross section is 103 barns (versus 13.6 for heavy water). Therefore, the removal of an essentially infinite $\mathrm{H}_{2} \mathrm{O}$ reflector can be expected to reduce the value of keff by a significant extent. The precise level is hard to gauge directly from simple hand calculations for complex configurations such as the ones currently being analyzed.

The effect of using a borated pipe is also seen to reduce significantly the $k_{\text {eff }}$ value. This is demonstrated in Case 8 whese a borated pipe is used with $2 \%$ natural boron which reduces the $k_{\text {eff }}$ value from 1.09 io 0.95 . The calculations for Cases 7 and 8 indicate that if may be possible to introduce practical methods for eliminating the possibility of recriticality via design. Finally, it is seen from results for Case 9 that the material of pipe can have a major influence on recriticatity. Use of an aluminum pipe material instead of steel significantly increases the keff value from 1.09 to 1.169 . The 
percentage of change in keff is twice that seen for Case 8 where use is made of a borated steel pipe. These results are not surprising, since boron absorption cross section for neutrons is significantly higher than for most other isotopes. This is clearly seen from Table 6 where the absorption cross sections for various isotopes and materials are tabulated. 12 The same can be said for the absorption cross-section of steel versus aluminum. As a rough measure, it is seen that the ratio of absorption cross sections for a steel (viz., mostly iron) pipe with and without $2 \%$ natural boron is equal to $6(=.02 \times$ 759/2.53). Again, the ratio of absorption cross sections for steel to aluminum amounts to $10.8(=2.53 / 0.235)$, which is close to twice as large for the case where $2 \%$ natural boron is added. Therefore, it is to be expected that the percentage change in keff should be twice as large for Case 9 versus for Case 8.

Several calculations were also conducted using the well known Hansen-Roach library ${ }^{14}$ [with suitable adjustments for selecting the resonance self-shielding crosssections $\left(s_{p}\right)$, as recommended in Ref. 15]. As seen in Table 4, although the predicted keff values are in the general vicinity of the ones predicted using the 39-group library, use of the 16-group Hansen-Roach cross-section library (at least under these conditions) can lead to significant loss of accuracy (underprediction of $k_{e f f}$ ) at least unde: the conditions tested.

\subsubsection{Analysis Results for Cases from Table 5}

Because the lumped core-debris configuration with $26 \mathrm{~kg}$ of $235 \mathrm{U}$ remained significantly subcritical, it was decided that lumped configurations in the ANS RCS would not lead to a recriticality threat. Therefore, only dispersed configurations were studied further with the current fuel loading in the ANS core (viz., $15 \mathrm{~kg}$ of $235 \mathrm{U}$ ). The results for individual cases are tabulated in Table 5. Figures 5 through 10 show $\mathrm{k}_{\mathrm{eff}}$ variation with the $(\mathrm{D}+\mathrm{H}) / 235 \mathrm{U}$ atom ratio in the core debris mixing zone.

Figure 5 indicates that $\mathrm{H}_{2} \mathrm{O}$ contamination in the RCS can significantly increase $k_{\text {eff }}$ values. This is because of enhanced moderation. However, the effect tapers off beyond $50 \% \mathrm{H}_{2} \mathrm{O}$ mole fraction and then starts tu decrease because of enhanced neutron absorption. These calculations demonstrate the need to keep $\mathrm{H}_{2} \mathrm{O}$ out of the RCS. Note, that for nonsevere accident conditions, recriticality from $\mathrm{H}_{2} \mathrm{O}$ ingress is prevented by design. Under such circumstances, control rods immediately insert to counter reactivity addition from light water entry into the RCS or into the reflector tank.

A linear decrease in keff is seen in Fig. 6 with increasing void fraction in the debris zone. With only $20 \%$ void fraction, the system keff drops from 1.04 to 0.89 (viz., a $15 \%$ decrease). The variation with increased void fraction also tends to indicate that a strong mechanism exists for limitirig a reactivity excursion event. A strong variation also is seen with dispersion length in Fig. 7. Reducing dispersion length causes a lumped mass-type geometry and decreases $k_{\text {eff. }}$. As seen in Fig. $7, \mathrm{k}_{\text {eff }}$ values do not increase significantly beyond a $1-\mathrm{m}$ dispersion length. Only a relatively mild variation with mixture temperature was noted. Figure 8 shows that a kefr decrease of about 7 to 8 cents $/{ }^{\circ} \mathrm{C}$ is achieved. This result indicates that a resonance absorption caused by Doppler broadening would provide enough negative feedback to compensate for positive reactivity insertion from increased thermal utilization by the fuel as the temperature increases. Overall, these variations demonstrate the significance and importance of properly modeling thermal hydraulic conditions during severe accidents.

Figure 9 shows that the amount of aluminum accompanying the core debris also can have a significant effect on system criticality. The variation of $k_{c}$ fr with aluminum mass is almost linear. It is not as strong as seen with variation with void fraction. However, it is significant and demonstrates the importance of proper core-melt progression modeling.

Finally, Fig. 10 demonstrates the importance of $\mathrm{B}^{10}$ in the fuel nixture. As can be seen, under EOC-type conditions when -30 to $40 \%$ of the $235 \mathrm{U}$ and all of the $\mathrm{B}^{10}$ are 
depleted, the $k_{\text {eff }}$ value goes up significantly from 1.04 to $\sim 1.11$ and then starts declining. Obviously, this variation with burnup is predicated on the $\mathrm{B}^{10}$ accompanying the fuel debris at $\mathrm{BOC}$ conditions in the first place.

\subsection{PREVENTION AND MITIGATION OF DEBRIS RECRITICALITY LOADS IN ANS}

An important byproduct of the results shown in Table 4 (Case 8) and in Fig. 10 deals with a possible approach for mitigation of recriticality. It demonstrates that incorporation of borated pipe regions in strategic locations could play a very important role in preventing recriticality. The preliminary calculation for Case 8 in Table 4 demonstrates this aspect, wherein a previously supercritical configuration was made significantly subcritical by borating the ANS outlet pipe.

Overall, it is clear that debris recriticality in the ANS RCS can be effectively prevented if dispersed configurations are avoided. These evaluations demonstrate, to the extent that they represent expected conditions, that a mechanism should be found that prevents dispersion of a large enough portion of core debris during severe accidents. If fuel dispersion is inevitable, it is clearly preferable to introduce design features that only allow small portions to disperse. Clearly, the need for prevention of debris dispersion has to be balanced with the need for maintaining debris coolability (which is enhanced with dispersion). Research efforts thus are to be focused toward analytically quantifying melt progression aspects with the potential for leading to recriticality, coupled with qualification via scaled experimentation.

If debris recriticality cannot be prevented by design, it may be necessary to introduce mitigative features for absorbing fuel-coolant-interaction (FCI) loads that may result. A key aspect that would need to be considered during such events deals with the mixture temperature. If temperatures reach high enough levels, significent additional energy would be available from aluminum-water chemical reactions that can release about $17 \mathrm{MJ}$ for every kilogram of aluminum being oxidized. Loads from explosive $\mathrm{FCI}$ may take the form of energetic missiles or shock waves. A study needs to be conducted to see whether such loads have the potential for causing containment failure. If so, strategically positioned missile shields or shock absorbers (such as foams) may prove useful in demonstrating overall containment integrity for entrapping radionuclides.

All in all, this is a clear case where a design fix that will prevent recriticality is far preferable to an extensive research program that may solve the problem. This is because not much is known on modeling and analysis of "transient" debris recriticality events.

\section{SUMMARY AND CONCLUSIONS}

This report has described salient aspects of benchmarking and validation of the KENO-SCALE neutronic code system for evaluation of system criticality, wherein lumped and dispersed core-debris configurations may arise during hypothetical severe accidents in the ANS. Benchmarking and validation were done against data from a series of critical experiments and also between various coles. These comparisons demonstrated the suitability of using the KENO-SCALE code system in conjunction with the 39-group cross-section library.

A detailed test matrix of calculations was developed for evaluating the potential of recriticality in the ANS RCS during severe accidents. The evaluations indicated that lumped configurations in the RCS would not pose a recriticality threat. However, significant potential exists for recriticality from dispersed debris configurations. Strong 
dependencies were noted on key thermal-hydraulic parameters such as mixture void fraction, $\mathrm{H}_{2} \mathrm{O}$ contamination, aluminum content in debris, and dispersion length. A relatively weak dependence was noted on mixture temperature. Mixture void fraction was evaluated to be the single most important parameter affecting recriticality. These calculations indicated the importance of proper core-melt progression and thermalhydraulic modeling. It was determined that prevention of recriticality in the ANS RCS may be achieved via limitation of debris dispersion, removal of light-water reflector on the outside of RCS piping, and strategic positioning of borated regions in the RCS piping. Alternate choices may also be possible (e.g., thickening of pipe walls for increased parasitic absorption, draining of light water surrounding heavy-water-filled RCS piping, or modifying pipe diameters to stay away from optimum $\mathrm{D} / 235 \mathrm{U}$ ratio regions).

At this stage it should be mentioned that the study conducted for this report has concentrated mainly on core debris recriticality in the ANS RCS, and then too, only steady state aspects have been researched. Future studies should endeavor, in conjunction with designers and PRA specialists, to evaluate the potential for recriticality in regions other than the ANS RCS. If a designed mitigative fix is not feasible or cannot be demonstrated, modeling and analyses should be conducted to evaluate transient aspects of recriticality, to form an informed judgment on possible FCI loads and structural interactions that have a potential for threatening containment integrity.

\section{REFERENCES}

1. C. D. West, "The Advanced Neutron Source: A New Reactor Based Facility for Neutron Research," Transactions of the American Nuclear Society 61, 375 (June 1990).

2. Advanced Neutron Source Plant Design Requirements, ORNL/TM-11625, Oak Ridge National Laboratory (1991).

3. F. T. Binford and E. N. Cramer, The High Flux Isotope Reactor, A Functional Description, ORNL-3572 (Rev. 2), Oak Ridge National Laboratory (June 1968).

4. J. P. Morin and M. L. Hyder, "The Reaction of Molten SRP Reactor Fuel with Water," ANS Workshop on the Safety of U-Al Fueled Reactors, Idaho Falls, Idaho (March 1990).

5. L. M. Petrie and N. F. LANDERS, "KENO V.A-An Improved Monte Carlo Criticality Program with Supergrouping," Vol. 2, Sect. F11 from SCALE: A Modular Coaie System for Performing Standardized Computer Analyses for Licensing Evaluation, NUREG/CR-0200 Rev. 2, ORNL/NUREG/CSD-2/R2, Oak Ridge National Laboratory (December 1984).

6. W. A. Rhoades and R. L. Childs, An Updated Version of DOT 4 One- and TwoDimensional Neutron/Photon Transport Code, ORNL-5851, Oak Ridge National Laboratory (July 1982).

7. J. W. Arwood et al., "Preparation and Benchmarking of ANSL-V Cross-Sections for Advanced Neutron Source Reactor Studies," Trans. Am. Nucl. Soc. 55, (1987).

8. G. E. Hansen and H. C. Paxton, Reevaluated Critical Specifications of Some Los Alamos Fast-Neutron Systems, LA-4208, Los Alamos Scientific Laboratory, (September 1969).

9. A. Staub et al., "Analysis of a Set of Critical Homogeneous U- $\mathrm{H}_{2} \mathrm{O}$ Spheres," NSE 34, 263-274 (1968).

10. R. N. Alcott, "Homogeneous Heavy Water Moderated Critical Assemblies Part 1 Experimental," NSE 1, 327-341 (1956).

11. S. Glasstone and M. C. Edlund, "The Elements of Nuclear Reactor Theory," Princeton, NJ (1966). 
12. G. E. Hansen and W. H. Roach, Six and Sixteen Group Cross-Sections for Fast and Intermediate Critical Assemblies, LAMS-2543, Los Alamos National Laboratory (December 1961).

13. C. M. Hopper and J. P. Renier, "Expanded and Applied Sixteen-Neutron-EnergyGroup Cross-Section Library," Trans. Amer. Nucl. Soc., 61 (June 1990).

14. D. W. Nigg, et al., "A PC-Based Version of KENO VA," Transactions of the American Nuclear Society, pp. 188-190, Vol. 61, 1990 American Nuclear Society Annual Meeting, Nashville, June 10-14, 1990.

15. Secretariat, American Nuclear Society, "American National Standard Design Requirements for Light Water Reactor Spent Fuel Storage Facilities at Nuclear Power Plants," ANSI/ANS-57.2-1983, October, 1983.

16. J. R. Lamarsh, "Nuclear Reactor Theory," Addison Wesley Publishing Company, 1966. 
Table 1. Severe accident characteristics of the ANS and other reactor systems

\begin{tabular}{|c|c|c|c|}
\hline Parameter & $\begin{array}{l}\text { Commercial } \\
\text { LWR }\end{array}$ & HFIR & ANS \\
\hline Power, MW(t) & 2600 & 85 & 300 \\
\hline Fuel & $\mathrm{UO}_{2}$ & $\mathrm{U}_{3} \mathrm{O}_{8}-\mathrm{Al}$ & $\mathrm{U}_{3} \mathrm{Si}_{2}-\mathrm{Al}$ \\
\hline Enrichment, m/o & $2-5^{2}$ & & \\
\hline Fuel cladding & Zircaloy & Al & $\mathrm{Al}$ \\
\hline Coolant/moderator & $\mathrm{H}_{2} \mathrm{O}$ & $\mathrm{H}_{2} \mathrm{O}$ & $\mathrm{H}_{2} \mathrm{O}$ \\
\hline $\begin{array}{l}\text { Coolant outlet } \\
\text { temp., }{ }^{\circ} \mathrm{C}\end{array}$ & 318 & $69^{\circ}$ & 85 \\
\hline $\begin{array}{l}\text { Avg. Fower } \\
\text { density, MW/1 }\end{array}$ & $<0.1$ & 1.7 & 4.5 \\
\hline $\begin{array}{l}\text { Clad melting } \\
\text { temp., }{ }^{\circ} \mathrm{C}\end{array}$ & 1850 & 580 & 580 \\
\hline $\begin{array}{l}\text { Hydrogen } \\
\text { generation } \\
\text { potential, } \mathrm{kg}\end{array}$ & 850 & 10 & 12 \\
\hline
\end{tabular}




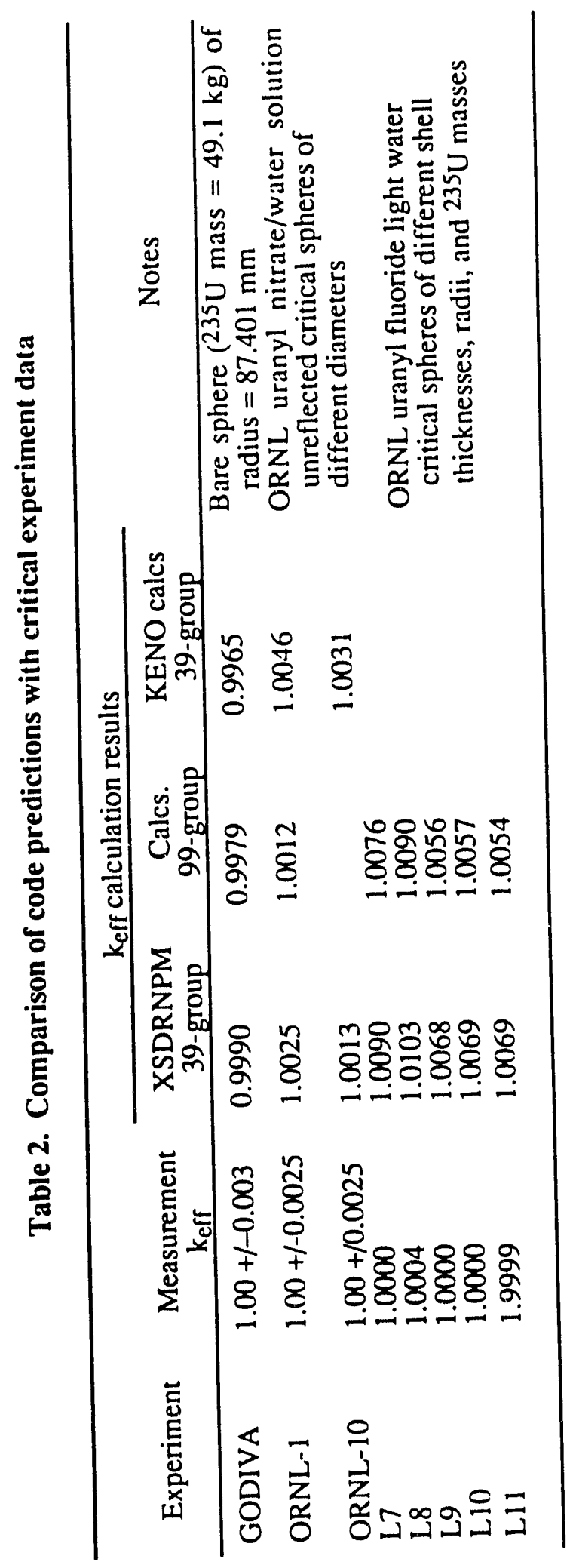


Table 3. KENO V.a sample problem comparison results

\begin{tabular}{|c|c|c|c|c|c|c|}
\hline \multirow{2}{*}{ Problem } & \multicolumn{2}{|c|}{ Reported } & \multicolumn{2}{|c|}{ Supplied Generator } & \multicolumn{2}{|c|}{ Alternate Generator } \\
\hline & $k$-eff & Deviation & k-eff & Deviation & $k$-eff & Deviation \\
\hline 1 & 0.9998 & 0.0041 & 1.0145 & 0.0035 & 0.9993 & 0.0040 \\
\hline 2 & 0.9998 & 0.0041 & 1.0145 & 0.0035 & 0.9993 & 0.0040 \\
\hline 3 & 1.0105 & 0.0055 & 1.0121 & 0.0054 & 1.0172 & 0.0050 \\
\hline 4 & 1.0117 & 0.0046 & 1.0161 & 0.0058 & 1.0116 & 0.0050 \\
\hline 5 & 1.0244 & 0.0038 & 1.0238 & 0.0035 & 1.0274 & 0.0036 \\
\hline 6 & 0.7562 & 0.0031 & 0.7451 & 0.0037 & 0.7515 & 0.0039 \\
\hline 7 & 1.0032 & 0.0044 & 1.0081 & 0.0043 & 1.0093 & 0.0040 \\
\hline 8 & 0.9436 & 0.0037 & 0.9446 & 0.0042 & 0.9440 & 0.0036 \\
\hline 9 & 2.3092 & 0.0067 & 2.3022 & 0.0081 & 2.3018 & 0.0049 \\
\hline 10 & 0.9998 & 0.0041 & 1.0145 & 0.0035 & 0.9993 & 0.0040 \\
\hline 11 & 0.9998 & 0.0041 & 1.0145 & 0.0035 & 1.0085 & 0.0040 \\
\hline 12 & 1.0065 & 0.0048 & 1.0127 & 0.0051 & 1.0199 & 0.0056 \\
\hline 13 & 1.0057 & 0.0042 & 1.0067 & 0.0044 & 0.9956 & 0.0044 \\
\hline 14 & 0.9990 & 0.0039 & 1.0070 & 0.0042 & 0.9916 & 0.0042 \\
\hline 15 & 1.0059 & 0.0049 & 1.0066 & 0.0042 & 1.0070 & 0.0043 \\
\hline 16 & 0.9901 & 0.0027 & 0.9977 & 0.0027 & 0.9937 & 0.0026 \\
\hline 17 & 0.9921 & 0.0158 & 1.0359 & 0.0176 & 1.0007 & 0.0185 \\
\hline 18 & 1.0067 & 0.0071 & 1.0385 & 0.0065 & 1.0282 & 0.0079 \\
\hline 19 & 1.0115 & 0.0051 & 1.0064 & 0.0048 & 1.0203 & 0.0057 \\
\hline 20 & 1.0063 & 0.0063 & 1.0119 & 0.0055 & 0.9975 & 0.0054 \\
\hline 21 & 0.9891 & 0.0033 & 0.9893 & 0.0037 & 0.9888 & 0.0033 \\
\hline 22 & 1.0026 & 0.0039 & 1.0145 & 0.0035 & 0.9994 & 0.0043 \\
\hline 23 & 0.9987 & 0.0041 & 1.0144 & 0.0035 & 1.0030 & 0.0042 \\
\hline 24 & 1.0068 & 0.0042 & 1.0062 & 0.0044 & 1.0014 & 0.0038 \\
\hline 25 & 1.0071 & 0.0041 & 1.0102 & 0.0042 & 1.0017 & 0.0038 \\
\hline
\end{tabular}


Table 4. Criticality calculations for lumped and dispersed geometries

\begin{tabular}{|c|c|c|c|c|}
\hline \multirow[b]{2}{*}{ Case } & \multirow[b]{2}{*}{ Configuration, debris constitution, etc. } & \multicolumn{3}{|c|}{$k_{\text {eff }}$ calculation results } \\
\hline & & KENO V.a & $\mathrm{KENO}^{b}$ & DORT/TORT \\
\hline 1 & $\begin{array}{l}\text { Lumped: } 175-\mathrm{mm} \text {-diam sphere of } \\
\mathrm{U}_{3} \mathrm{Si}_{2} \text { at bottom of } \mathrm{D}_{2} \mathrm{O} \text {-filled steel } \\
\text { pipe, submerged in } \mathrm{H}_{2} \mathrm{O} \text { (pipe } \mathrm{ID}= \\
488 \mathrm{~mm} \text { ); } 26 \mathrm{~kg} 235 \mathrm{U}\end{array}$ & 0.9674 & & $0.999,0.960$ \\
\hline 2 & $\begin{array}{l}\text { Lumped: } 220 \text {-m-diam sphere of } \mathrm{U}_{3} \mathrm{Si}_{2}- \\
\mathrm{Al} \text { at bottom of } \mathrm{D}_{2} \mathrm{O} \text {-filled steel pipe, } \\
\text { submerged in } \mathrm{H}_{2} \mathrm{O} \text { (pipe ID }=488 \\
\mathrm{~mm} \text { ); } 24 \mathrm{~kg} 235 \mathrm{U}\end{array}$ & 0.873 & 0.850 & 0.866 \\
\hline 3 & $\begin{array}{l}\text { Lumped: Same as for Case 1, except } \\
\text { that shape of lump is hemisphere; } \\
22.54 \mathrm{~kg} 235 \mathrm{U}\end{array}$ & 0.819 & & \\
\hline 4 & $\begin{array}{l}\text { Dispersed: } \mathrm{U}_{3} \mathrm{Si}_{2} \text { mass uniformly } \\
\text { suspended in a } 1-\mathrm{m} \text {-long section of } \\
\mathrm{D}_{2} \mathrm{O} \text {-filled steel, } \mathrm{H}_{2} \mathrm{O} \text { submerged pipe } \\
(\mathrm{ID}=488 \mathrm{~mm}) ; 26 \mathrm{~kg} \text { of } 235 \mathrm{U}\end{array}$ & 1.090 & & 1.084 \\
\hline 5 & $\begin{array}{l}\text { Dispersed: Same as Case } 4 ; 15 \mathrm{~kg} \text { of } \\
235 \mathrm{U}\end{array}$ & 1.070 & 1.030 & \\
\hline 6 & $\begin{array}{l}\text { Dispersed: Sanie as Case } 4 \text { except that } \\
\text { the dispersion lenght is } 2 \mathrm{~m} \text { long; } 4.5 \\
\mathrm{~kg} \text { of } 235 \mathrm{U}\end{array}$ & 0.844 & & \\
\hline 7 & $\begin{array}{l}\text { Dispersed: Same as Case } 4 \text { except that } \\
\text { the } \mathrm{H}_{2} \mathrm{O} \text { reflector is absent }\end{array}$ & 0.9285 & & 0.9336 \\
\hline 8 & $\begin{array}{l}\text { Dispersed: Same as Case } 4 \text { except that } \\
\text { steel pipe has } 2 \text { w/o of natural boron }\end{array}$ & 0.9498 & & 0.9486 \\
\hline 9 & $\begin{array}{l}\text { Dispersed: Same as Case } 4 \text { except that } \\
\text { pipe material is made with aluminum }\end{array}$ & 1.1697 & & \\
\hline
\end{tabular}
system.

${ }^{a}$ These calculations were done with 39-group cross-section library in the SCALE

$b$ These calculations used the 16-group Hansen Roach cross-section library. 


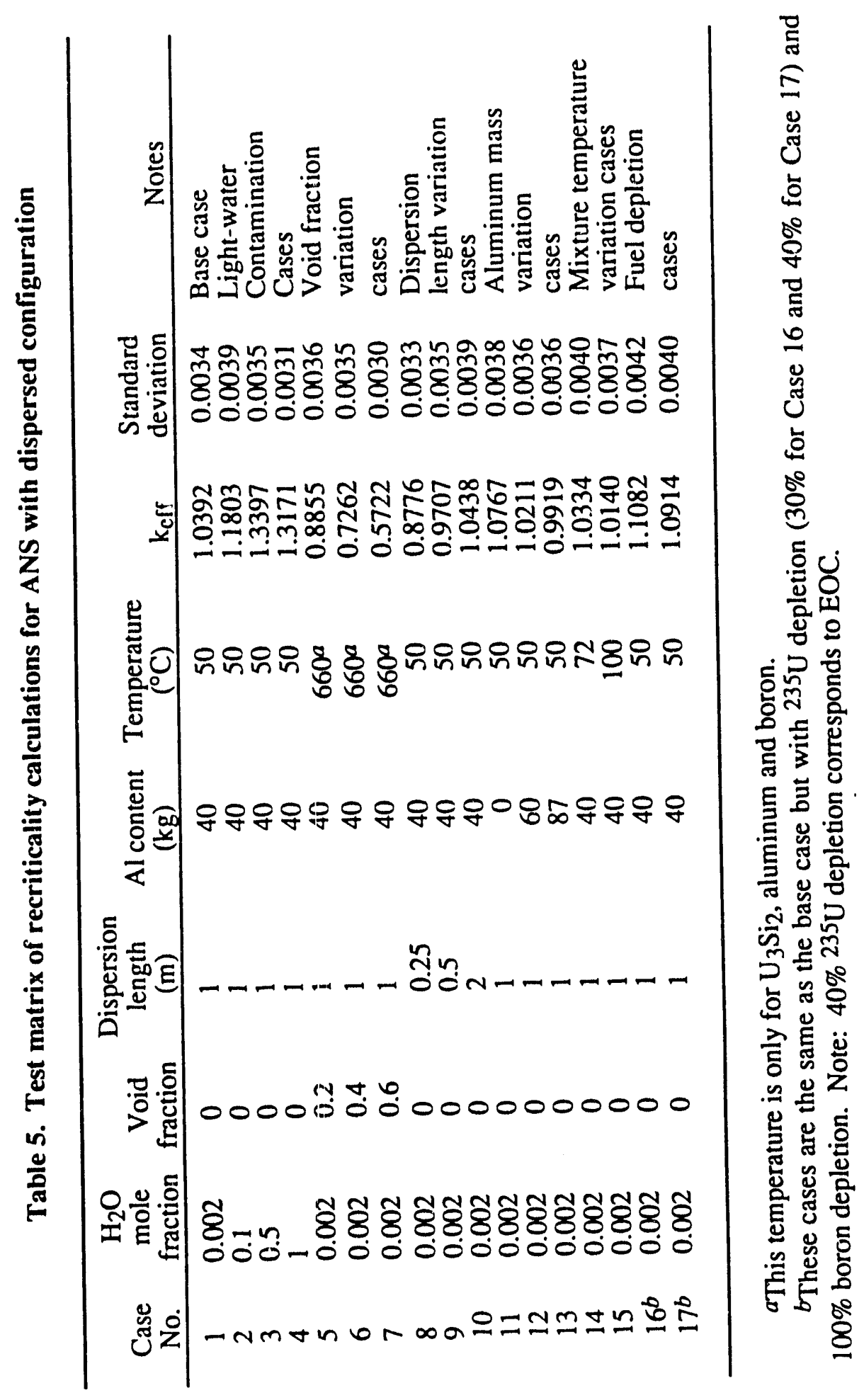


Table 6. Absorption Cross sections for Selected Isotopes/Materials

\begin{tabular}{lc}
\hline Isotope/Material & Cross section (barns) \\
\hline $\mathrm{Al}$ & 0.235 \\
$\mathrm{H}^{1}$ & $332 \mathrm{mb}$ \\
$\mathrm{H}^{2}$ & $0.5 \mathrm{mb}$ \\
$\mathrm{B}^{10}$ & 3837 \\
$\mathrm{~B}^{11}$ & $5 \mathrm{mb}$ \\
$\mathrm{B}$ (Natural) & 759 \\
$\mathrm{D}_{2} \mathrm{O}$ & .0010 \\
$\mathrm{Fe}$ & 2.53 \\
$\mathrm{H}_{2} \mathrm{O}$ & 0.664 \\
$\mathrm{I}$ & 6.4 \\
$\mathrm{U}^{235}$ & 678 \\
$\mathrm{U}^{238}$ & 2.73 \\
$\mathrm{Xe}^{23}$ & 24 \\
$\mathrm{Xe}^{135}$ & $2.7 \times 10^{6}$ \\
\hline
\end{tabular}

${ }^{*}$ ) - Cross sections at 0.0235 ev or 2200 $\mathrm{m} / \mathrm{s}$ - Ref. 15 . 


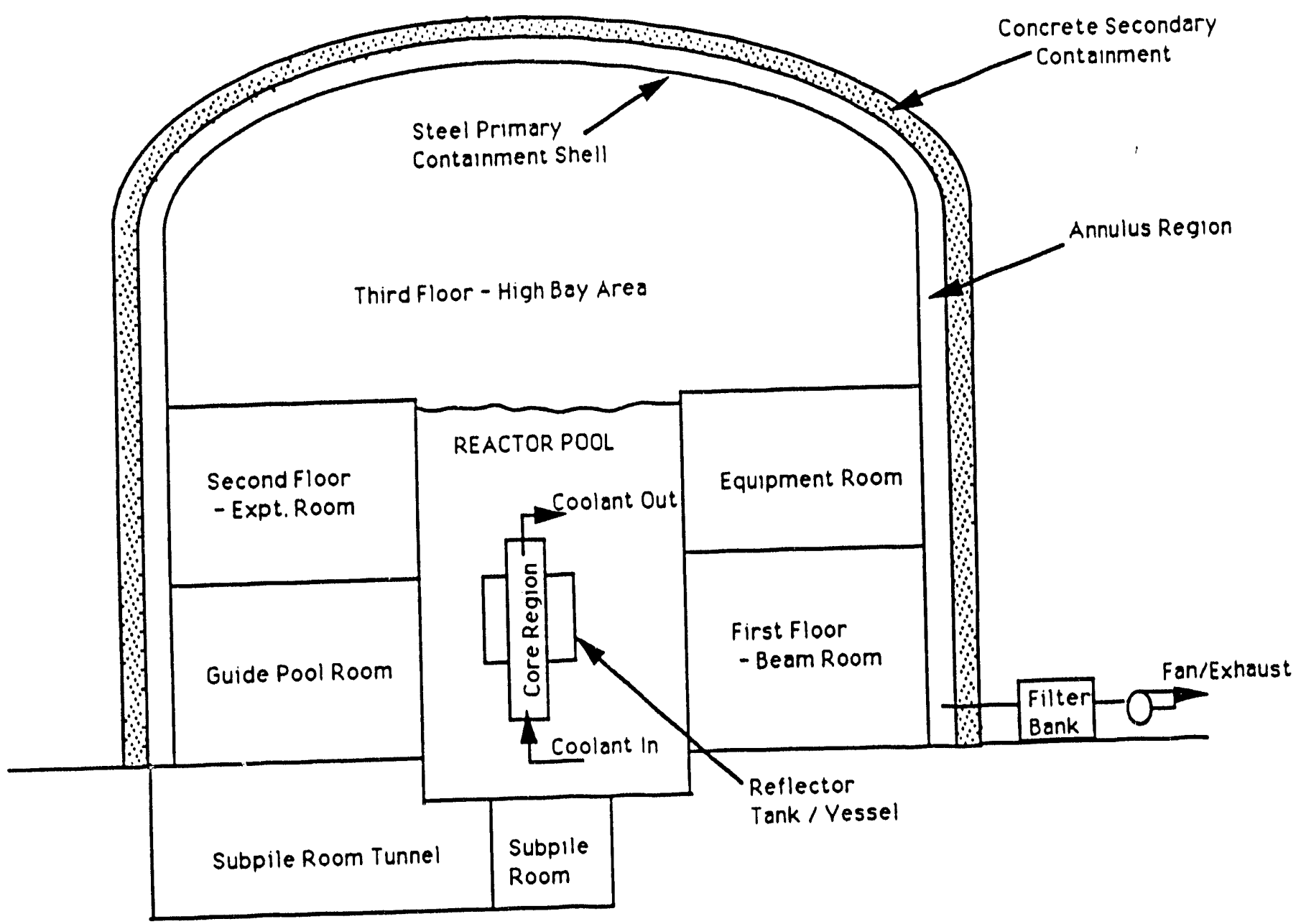

Figure 1. Schematic representation of ANS reactor and containment. 


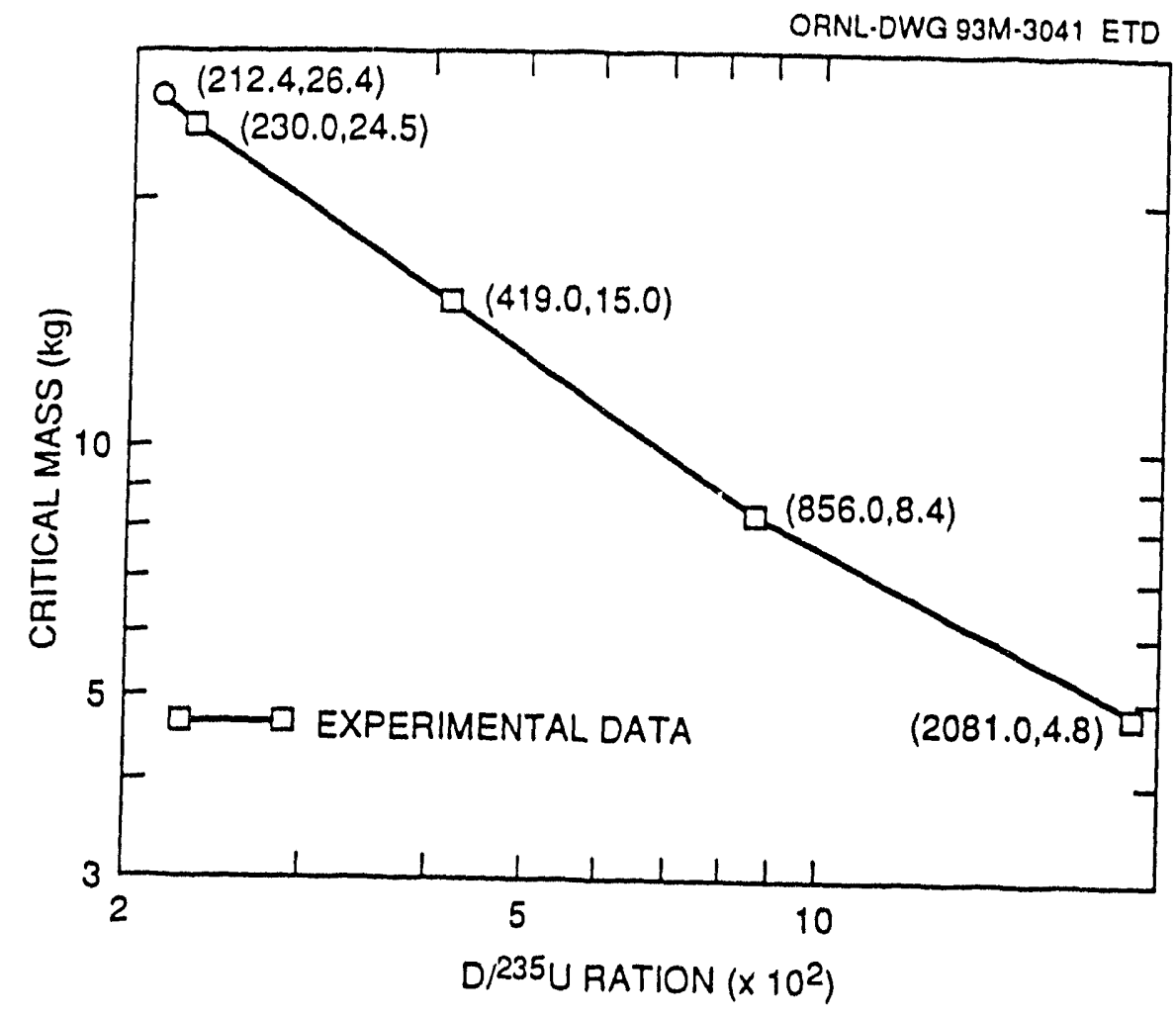

Fig. 2. Deuterium-to-235U ratio versus critical mass for enriched uranyl fluoride / heavy water bare cylindrical critical experimental data. 


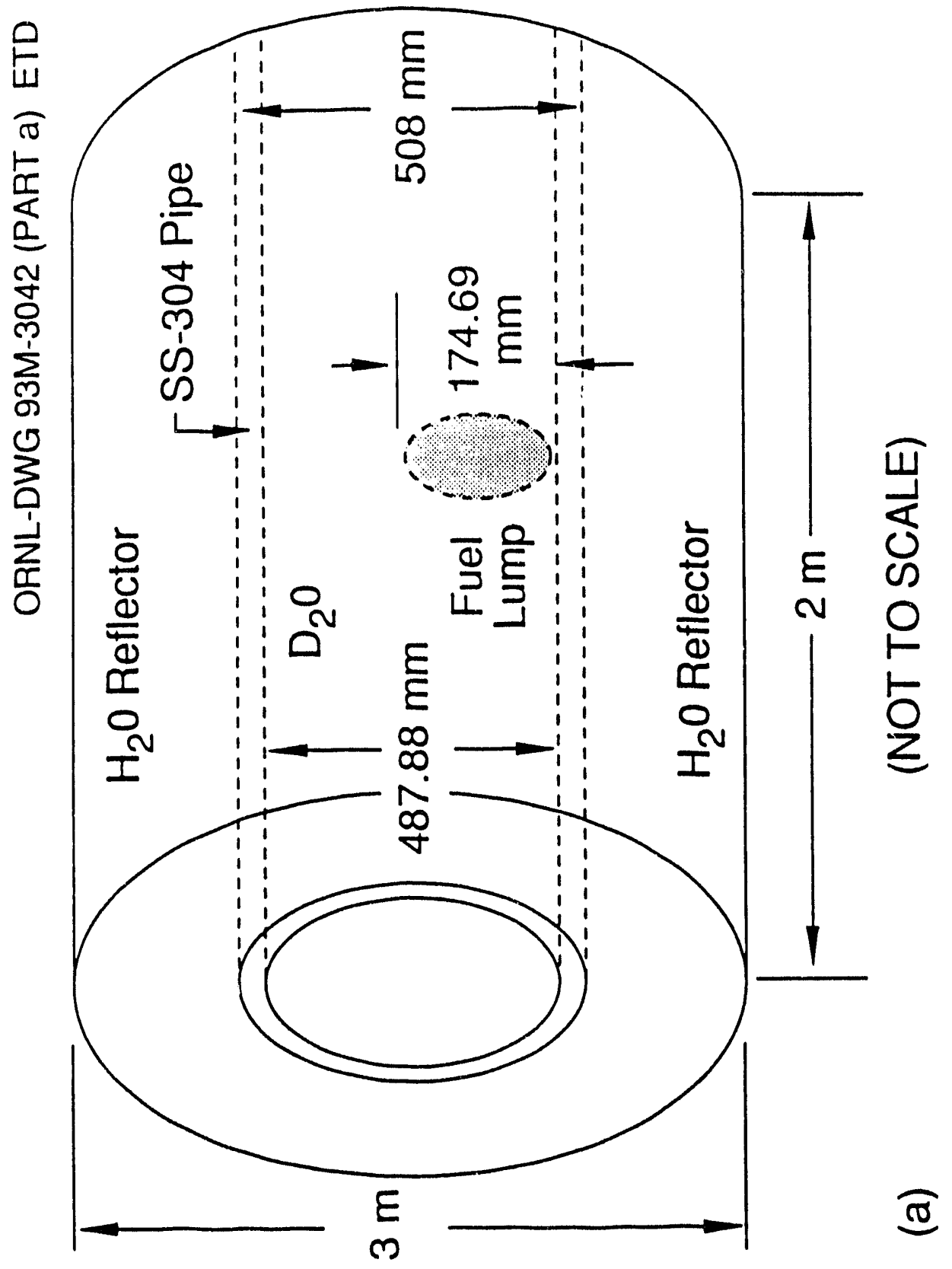

Figure 3a. Schematic representation of spherical lumped core debris configuration in ANS pipe for recriticality evaluations. 


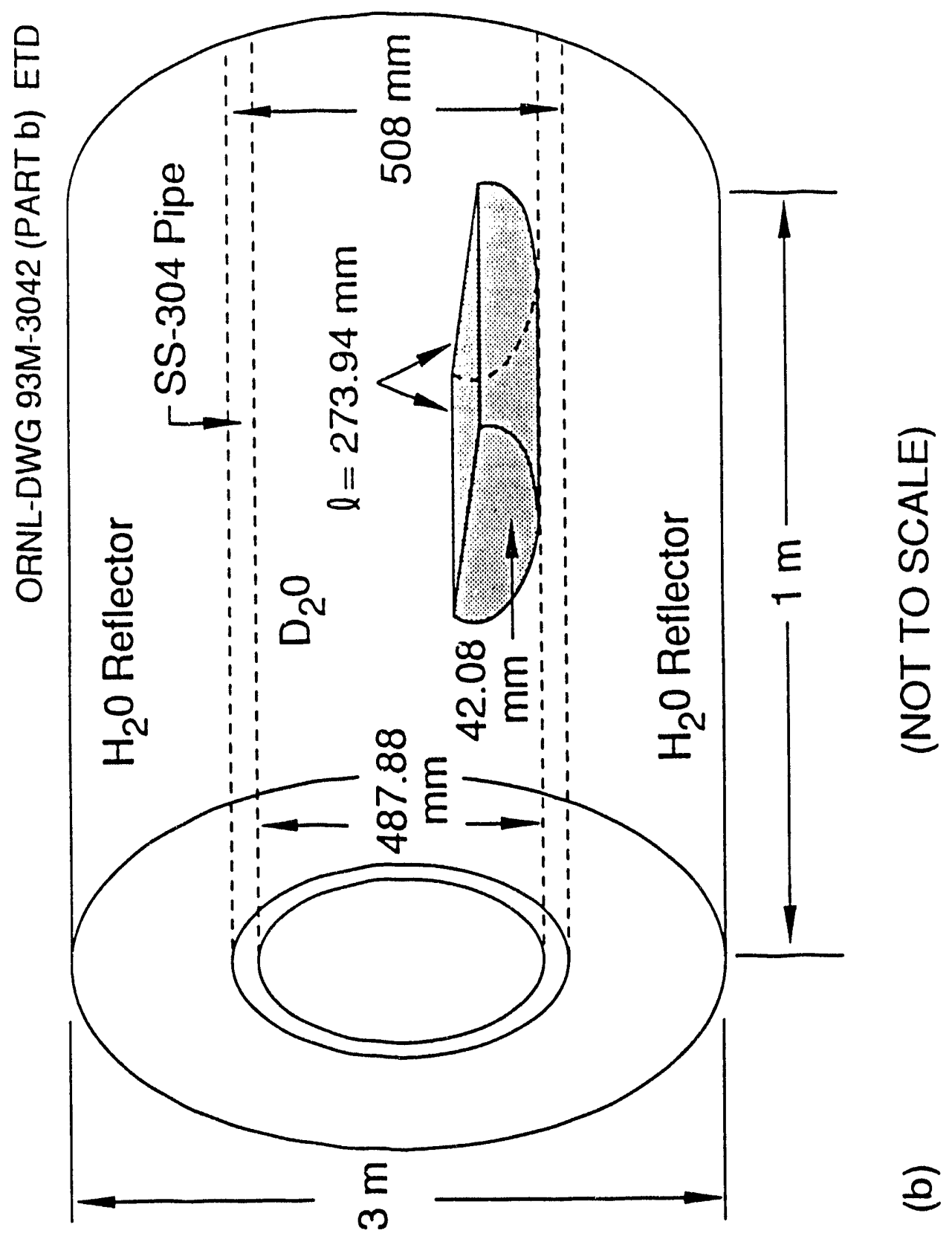

Figure 3b. Schenutic representation of hemispherical lumped core debris configuration in AN'S pipe for recriticality evaluations. 


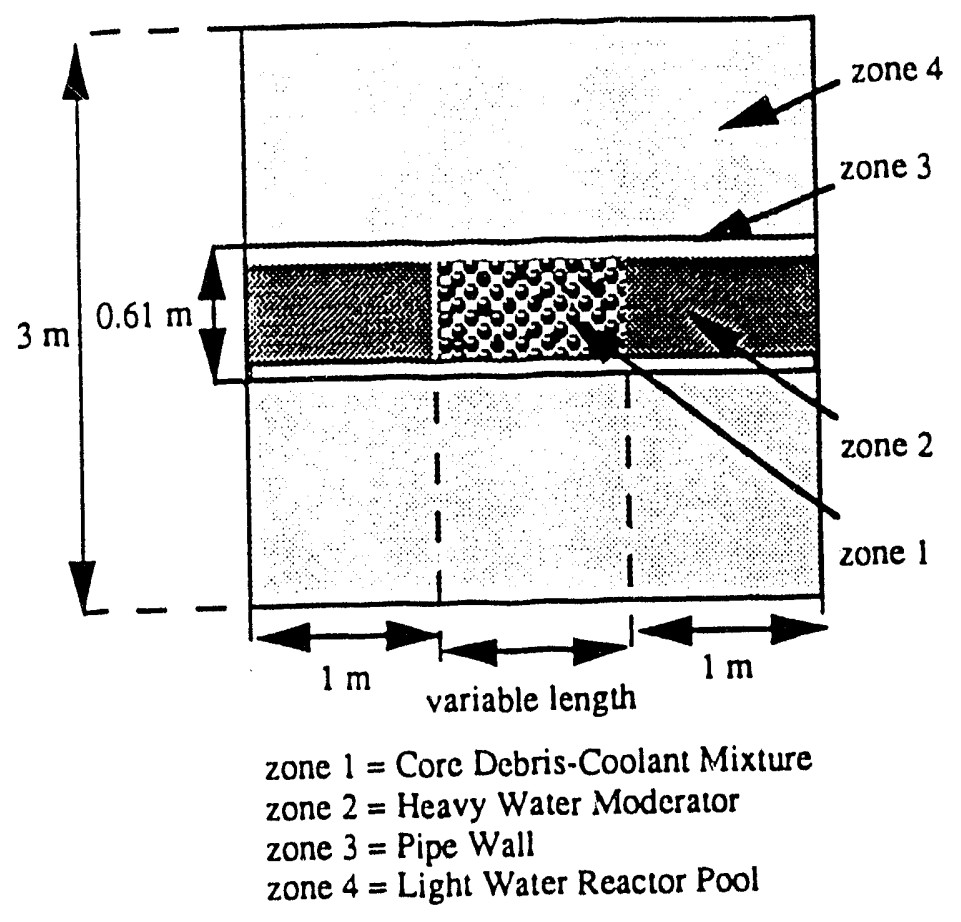

Fig. 4. Schematic representation of dispersed core debris configuration in ANS outlet pipe for recriticality evaluations. 


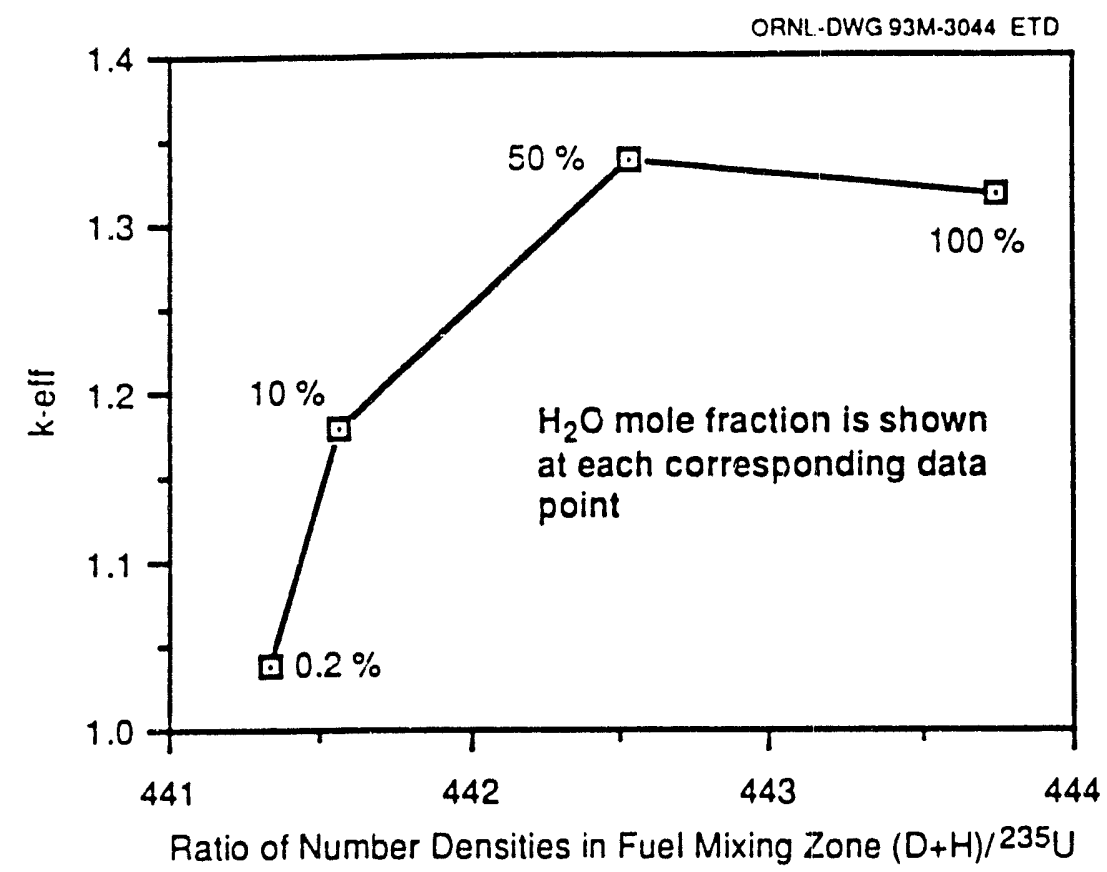

Fig. 5. Effect of light water contamination on keff. 


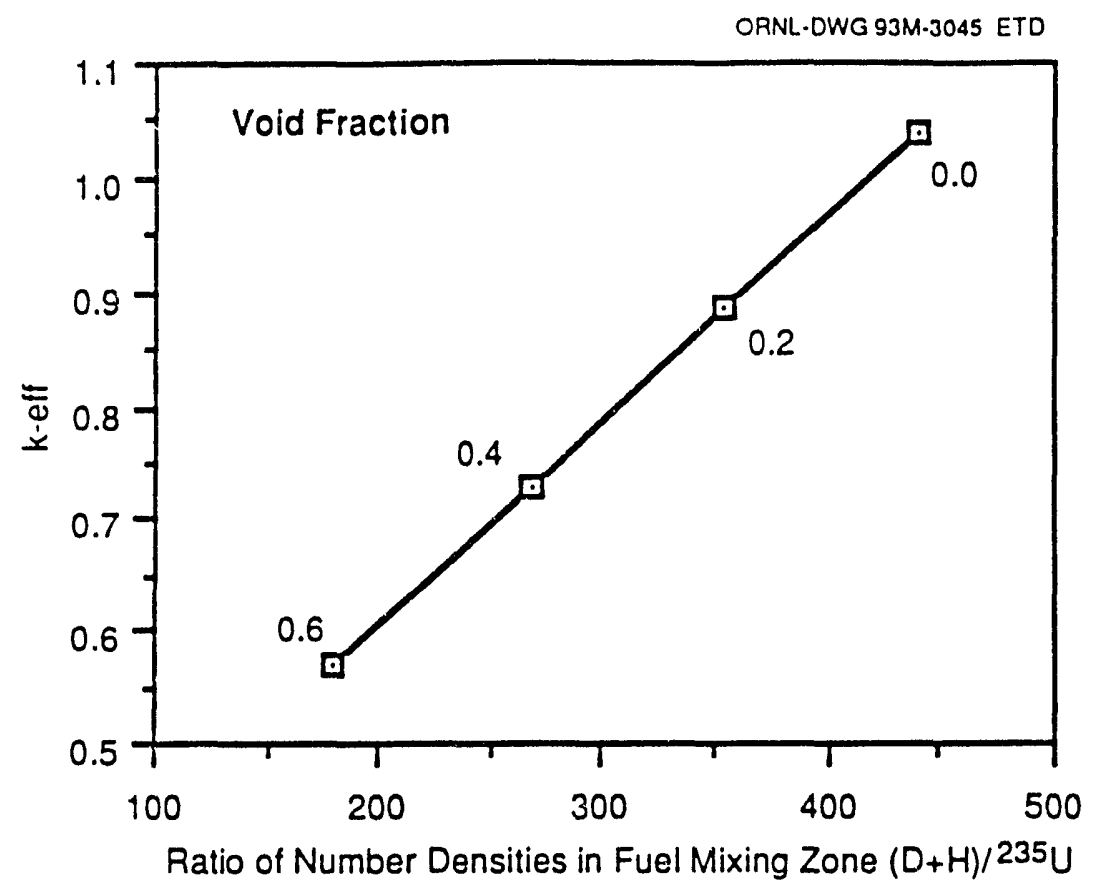

Fig. 6. Effect of void fraction on keff. 


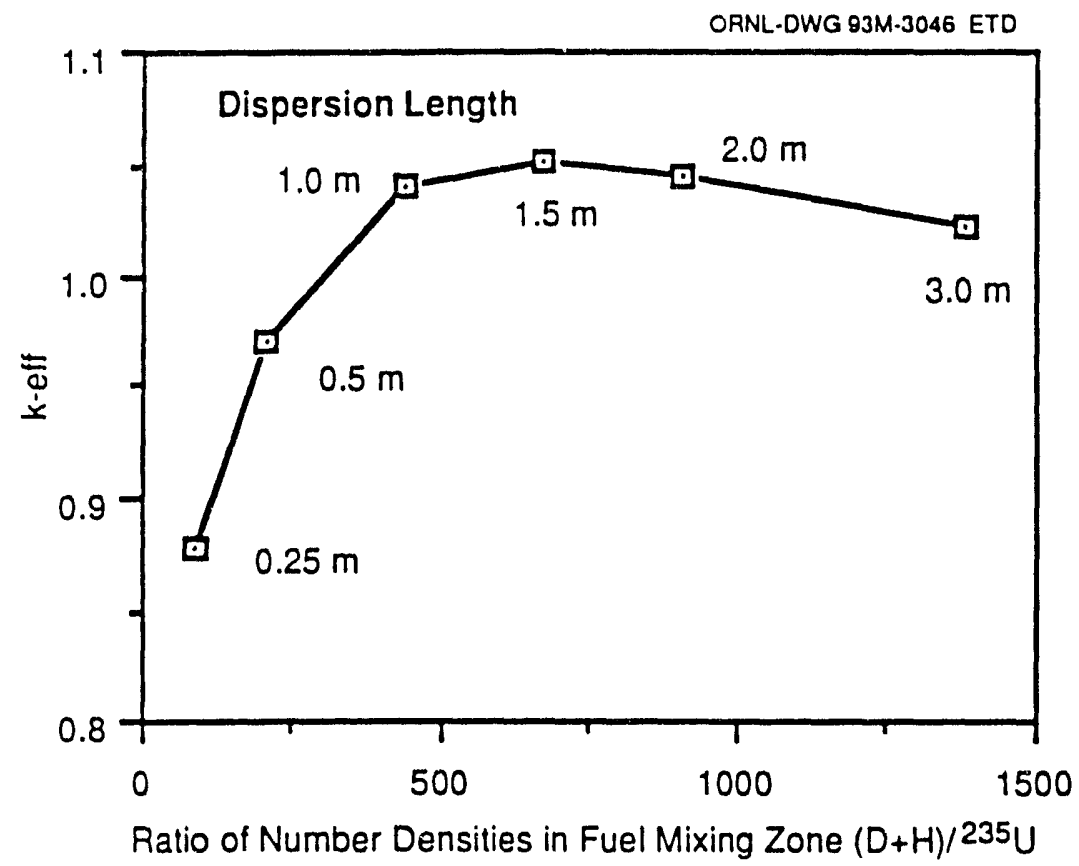

Fig. 7. Effect of dispersion length on keff. 


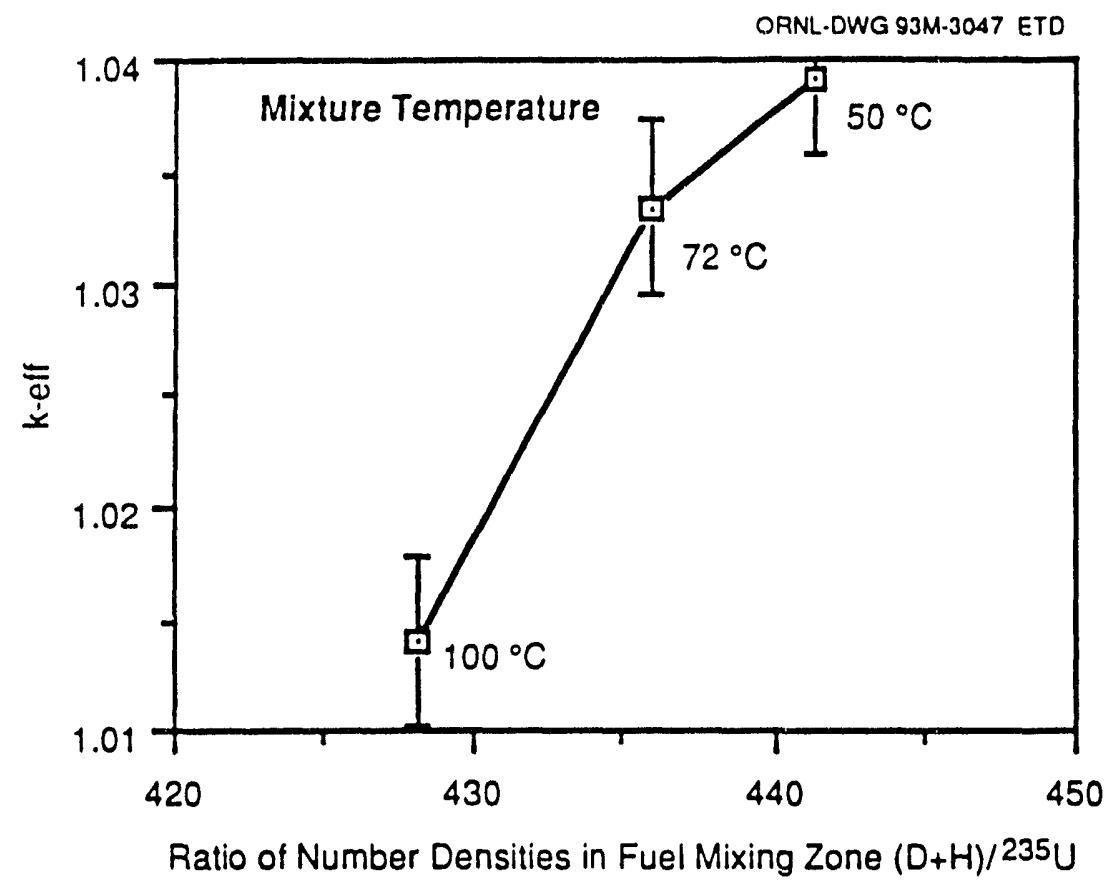

Fig. 8. Effect of fuel temperature on keff. 


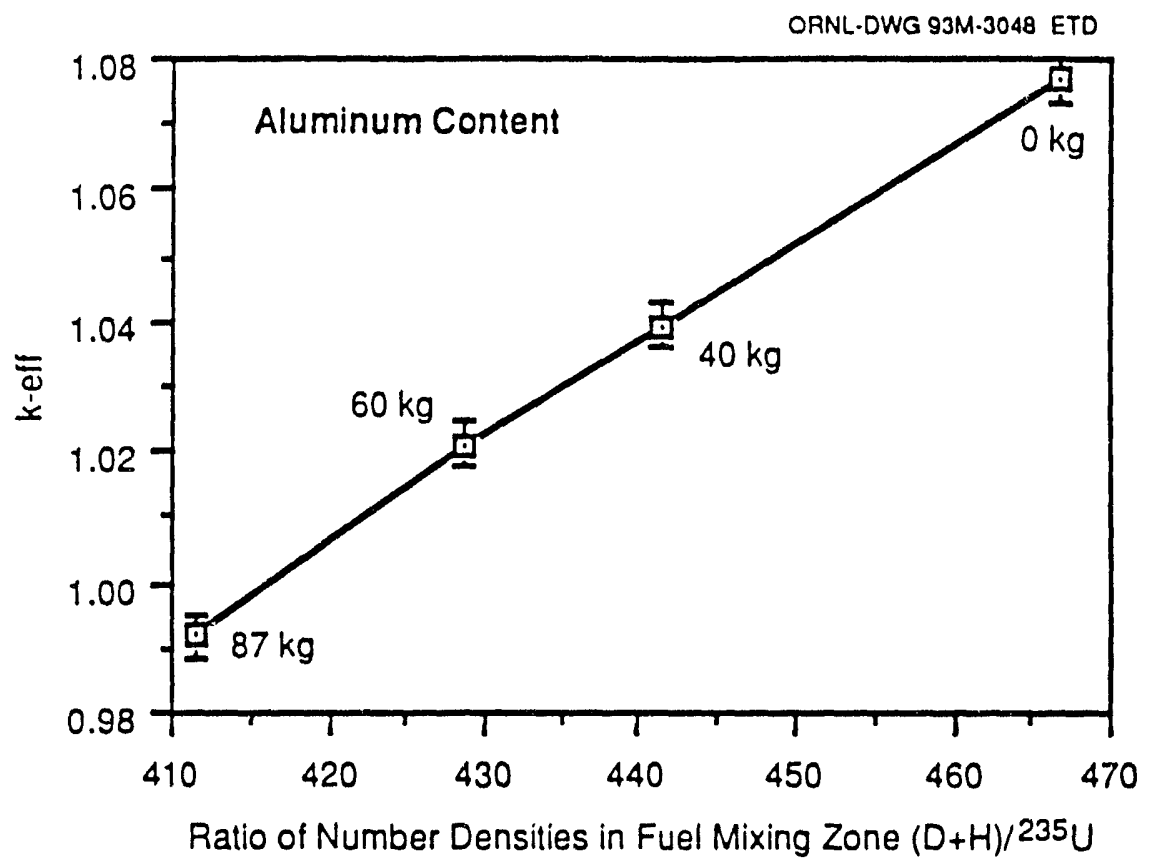

Fig. 9. Effect of aluminum content on keff. 


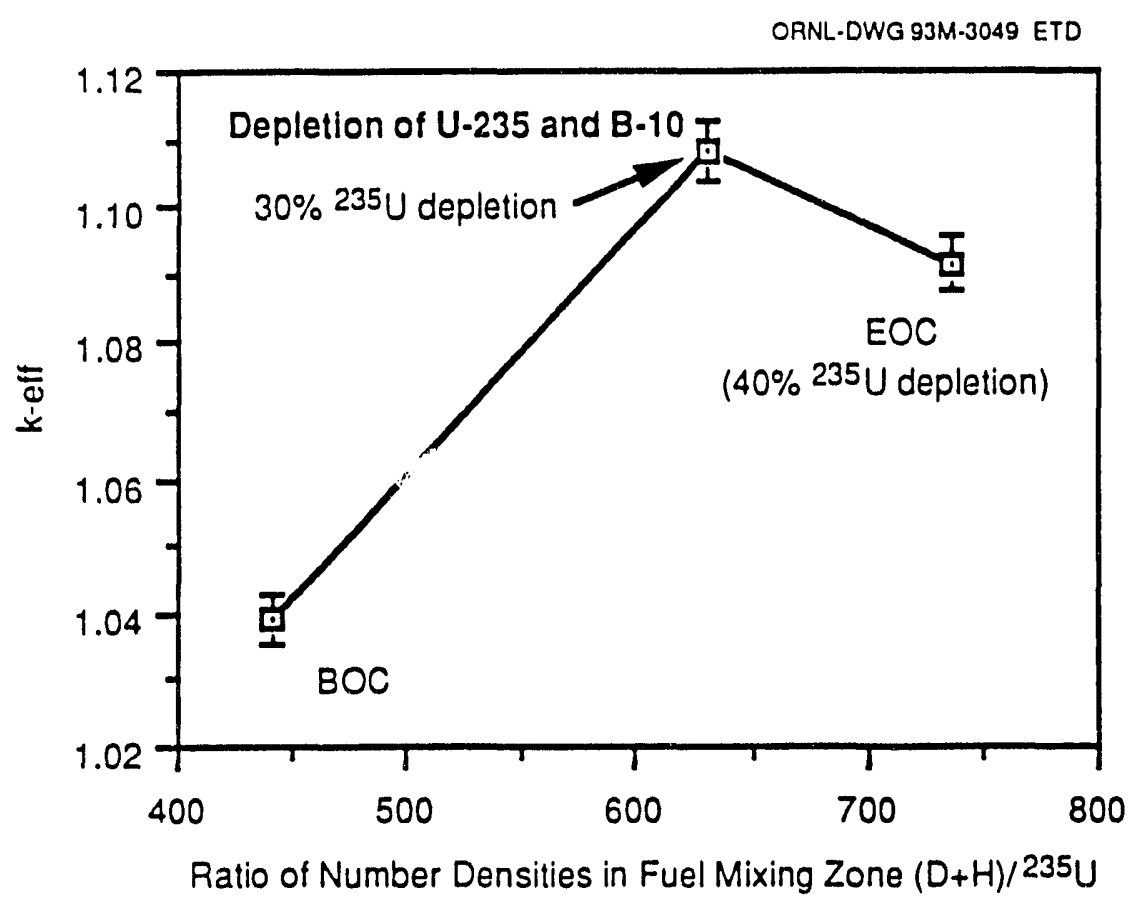

Fig. 10. Effect of fuel depletion on keff. 
Internal Distribution List

$\begin{array}{llll}\text { 1. } & \text { S. J. Chang } & 17 . & \text { J. Richard } \\ 2 . & \text { D. H. Cook } & 18 . & \text { D. L. Selby } \\ \text { 3. } & \text { W. G. Craddick } & 19 . & \text { D. B. Simpson } \\ \text { 4. } & \text { E. C. Fox } & 20 . & \text { C. O. Slater } \\ \text { 5. } & \text { G. Flannagan } & 21 . & \text { J. Stiegler } \\ 6 . & \text { U. Gat } & 22-24 . & \text { R. P. Taleyarkhan } \\ \text { 7. } & \text { V. Georgevich } & 23 . & \text { S. Valenti } \\ 8 . & \text { S. R. Greene } & 24 . & \text { C. D. West } \\ 9 . & \text { R. M. Harrington } & 25 . & \text { ORNL Patent Section } \\ 10 . & \text { S. A. Hodge } & 26 . & \text { Central Research Library } \\ 11 . & \text { J. E. Jones Jr. } & 27-28 . & \text { Laboratory Records } \\ 12 . & \text { S. H. Kim } & & \text { Department } \\ 13 . & \text { T. S. Kress } & 29 . & \text { Laboratory Records (RC) } \\ 14 . & \text { R. H. Morris } & & \\ 15 . & \text { D. L. Moses } & & \\ 16 . & \text { L. J. Ott } & & \end{array}$

External Distribution

30. J. Close, Idaho National Laboratories, P. O. Box 1625, EG\&G, Idaho Falls, Idaho 83415

31. M. L. Corradini, Department of Nuclear Engineering, 1500 Johnson Drive, University of Wisconsin, Madison, Wisconsin, 53706-1687

32. F. Eltawila, USNRC, Division of Systems of Research, Office of Regulatory Research, Washington, D.C., 20555

33. M. L. Hyder, SRTC, Westinghouse Savannah River, Co., 1991 South Centennial Avenue, Bldg. 1, Aiken, South Carolina, 29803

34. R. T. Lahey, Nuclear Engineering and Engineering Physics, Rensselaer Polytechnic Institute, JEC 5048, Troy, New York, 12180-3590

35. M. Z. Podowoski, Nuclear Engineering and Engineering Physics, Rensselaer Polytechnic Institute, JEC 5048, Troy, New York, 12180-3590

36. J. Rsyskamp, Idaho National Laboratories, P. O. Box 1625, EG\&G, Idaho Falls, Idaho 83415

37. R. Wright, USNRC, Division of Systems of Research, Office of Regulatory Research, Washington, D.C., 20555

38. DOE, Office of Scientific and Technical Information, P.O. Box 62, Oak Ridge, Tennessee 37831

39. AMERD, Richard Egli, U.S. Department of Energy, Oak Ridge Operations Office, P. O. Box 2001, Oak Ridge, Tennessee 37831-8600 

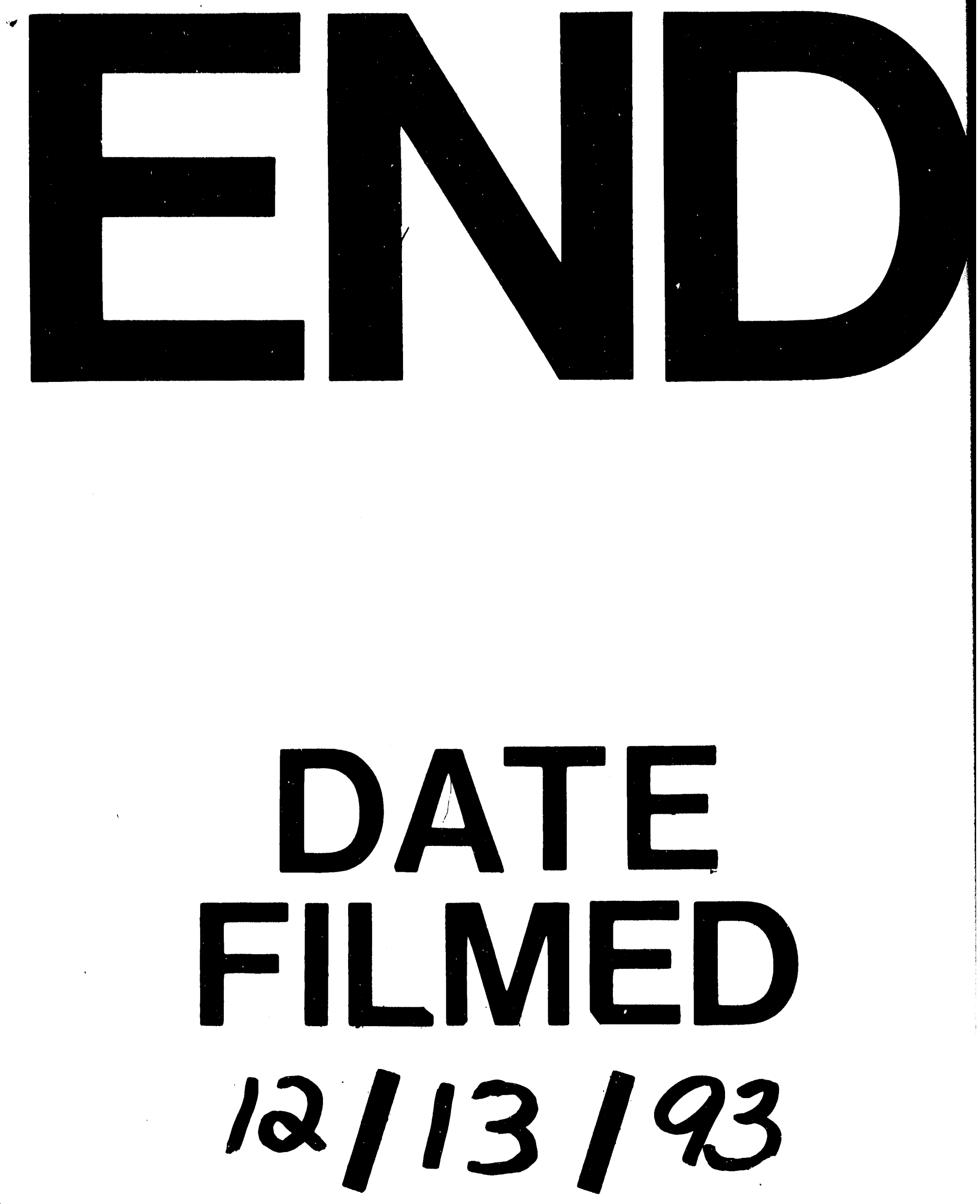

1 


$$
\text { - }
$$

